HOW TO STUDY MODERN POETRY 


\section{Study Guides}

Series editors: John Peck and Martin Coyle

\section{IN THE SAME SERIES}

How to Begin Studying English Literature (second edition)

Nicholas Marsh

How to Study a Jane Austen Novel (second edition) Vivien Jones

How to Study Chaucer (second edition) Robert Pope

How to Study a Joseph Conrad Novel Brian Spittles

How to Study a Charles Dickens Novel Keith Selby

How to Study Foreign Languages Marilyn Lewis

How to Study an E. M. Forster Novel Nigel Messenger

How to Study a Thomas Hardy Novel John Peck

How to Study a D. H. Lawrence Novel Nigel Messenger

How to Study James Joyce John Blades

How to Study Linguistics Geoffrey Finch

How to Study Milton David Kearns

How to Study Modern Drama Kenneth Pickering

How to Study Modern Poetry Tony Curtis

How to Study a Novel (second edition) John Peck

How to Study a Poet (second edition) John Peck

How to Study a Renaissance Play Chris Coles

How to Study Romantic Poetry Paul O'Flinn

How to Study a Shakespeare Play (second edition) John Peck and

Martin Coyle

How to Study Television Keith Selby and Ron Cowdery

Literary Terms and Criticism (second edition) John Peck and

Martin Coyle

Practical Criticism John Peck and Martin Coyle

Studying History (second edition) Jeremy Black and Don M. MacRaild

Linguistic Terms and Concepts Geoffrey Finch 


\section{HOW TO STUDY \\ MODERN POETRY}

\section{Tony Curtis}




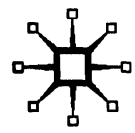

(C) Tony Curtis 1990

All rights reserved. No reproduction, copy or transmission of this publication may be made without written permission.

No paragraph of this publication may be reproduced, copied or transmitted save with written permission or in accordance with the provisions of the Copyright, Designs and Patents Act 1988, or under the terms of any licence permitting limited copying issued by the Copyright Licensing Agency, 90 Tottenham Court Road, London W1T 4LP.

Any person who does any unauthorised act in relation to this publication may be liable to criminal prosecution and civil claims for damages.

The author has asserted his right to be identified as the author of this work in accordance with the Copyright, Designs and Patents Act 1988.

Published by

PALGRAVE

Houndmills, Basingstoke, Hampshire RG21 6XS and 175 Fifth Avenue, New York, N. Y. 10010

Companies and representatives throughout the world

PALGRAVE is the new global academic imprint of

St. Martin's Press LLC Scholarly and Reference Division and

Palgrave Publishers Ltd (formerly Macmillan Press Ltd).

ISBN 978-0-333-46729-9 ISBN 978-1-349-10285-3 (eBook)

DOI 10.1007/978-1-349-10285-3

This book is printed on paper suitable for recycling and made from fully managed and sustained forest sources.

A catalogue record for this book is available from the British Library.

$\begin{array}{llllll}12 & 11 & 10 & 9 & 8 & 7\end{array}$

$\begin{array}{llllll}06 & 05 & 04 & 03 & 02 & 01\end{array}$ 


\section{Contents}

General editors' preface vii

Acknowledgements viii

1 Shapes and Puzzles 1

2 The Making of a Poem $\quad 29$

3 The 1940s and 1950s $\quad 59$

4 The 1960s $\quad 91$

$\begin{array}{lll}5 & \text { The 1970s } & 117\end{array}$

$\begin{array}{lll}6 & \text { The 1980s } & 137\end{array}$

7 Writing an Analysis $\quad 159$

$\begin{array}{lr}\text { Further reading } & 165\end{array}$ 


\section{$\overline{\text { General editors' preface }}$}

EVERYBODY who studies literature, either for an examination or simply for pleasure, experiences the same problem: how to understand and respond to the text. As every student of literature knows, it is perfectly possible to read a book over and over again and yet still feel baffled and at a loss as to what to say about it. One answer to the problem, of course, is to accept someone else's view of the text, but how much more rewarding it would be if you could work out your own critical response to any book you choose or are required to study.

The aim of this series is to help you develop your critical skills by offering practical advice about how to read, understand and analyse literature. Each volume provides you with a clear method of study so that you can see how to set about tackling texts on your own. While the authors of each volume approach the problem in a different way, every book in the series attempts to provide you with some broad ideas about the kind of texts you are likely to be studying and some broad ideas about how to think about literature; each volume then shows you how to apply these ideas in a way which should help you construct your own analysis and interpretation. Unlike most critical books, therefore, the books in this series do not convey someone else's thinking about a text, but encourage you to think about a text for yourself.

Each book is written with an awareness that you are likely to be preparing for an examination, and therefore practical advice is given not only on how to understand and analyse literature, but also on how to organise a written response. Our hope is that although these books are intended to serve a practical purpose, they may also enrich your enjoyment of literature by making you a more confident reader, alert to the interest and pleasure to be derived from literary texts. 


\section{Acknowledgements}

The author and publishers wish to thank the following who have kindly given permission for the use of copyright material: Carcanet Press Ltd for 'This is Just to Say' from The Collected Poems 1909-1939 by William Carlos Williams, edited by A. Walton Litz and C. MacGowan, 1987; and 'The Hare' from Selected Poems by Gillian Clarke; Chatto and Windus Ltd for 'Mama Dot Warns Against an Easter Rising' from Mama Dot by Fred Aguiar; Collins Publishers for 'A Peasant' by R. S. Thomas; Faber and Faber Ltd for 'Cuba' from Why Brownlee Left by Paul Muldoon; 'Death of a Naturalist' by Seamus Heaney from the book of the same name; 'Thrushes' from Lupercal by Ted Hughes; and 'The Whitsun Weddings' by Philip Larkin from the book of the same name; David Higham Associates Ltd on behalf of the estate of the author for 'A Refusal to Mourn' from The Poems by Dylan Thomas; Olwyn Hughes Literary Agency on behalf of Ted Hughes for 'Daddy' from Collected Poems by Sylvia Plath, Faber and Faber. Copyright (C) 1965, 1981 by Ted Hughes; W. W. Norton \& Company, Inc. for 'Aunt Jennifer's Tigers' and 'Translations' from The Fact of a Doorframe: Poems Selected and New, 1950-1984 by Adrienne Rich. Copyright (C) 1984 by Adrienne Rich. Copyright (C) 1975, 1978 by W. W. Norton \& Company, Inc. Copyright (C) 1981 by Adrienne Rich; Oxford University Press for 'Vergissmeinnicht' from The Complete Poems of Keith Douglas, edited by Desmond Graham, 1978; Poetry Wales Press for 'Water' from Selected Poems by Leslie Norris, 1986; Anthony Sheil Associates Ltd on behalf of the author for 'In the Theatre' by Daniel Abse; Unwin Hyman Ltd for 'All Day it has Rained' by Alun Lewis from Selected Poems, eds Hooker and Lewis, Allen and Unwin.

Every effort has been made to trace all the copyright holders, but if any have been inadvertently overlooked the publishers will be pleased to make the necessary arrangement at the first opportunity. 